\title{
The transversal strength of acrylic resin plate after being immersed soaking in noni fruit (Morinda citrifolia Linn.) juice
}

Sri Redjeki Indiani

Department of Dental Material

Faculty of Dentistry, Airlangga University

Surabaya - Indonesia

\begin{abstract}
The disadvantages of acrylic resin plate are liquid absorption and porosity, allowing microorganisms to grow and multiply resulting in inflammation in the oral cavity. The juice of the noni fruit (Morinda citrifolia Linn.) contains active flavonoid and atsiri oil. Flavonoid is a phenol substance that degrades acrylic resin plate in prolonged contact. The purpose of this study was to examine the transversal strength of acrylic resin plate after being immersed in noni fruit juice. An acrylic resin plate of $65 \times 10 \times 2.5 \mathrm{~mm}$ was immersed in $4 \%, 6 \%, 8 \%, 10 \%$, and 12\% concentrations of noni fruit juice and distilled water in a control group for 31, 46, and 61 days. The transversal strength of acrylic resin plate was tested using an autograph with a crosshead speed of 1/10mm/second; the distance for the two supporting parts was $50 \mathrm{~mm}$. The data was analyzed by using a One-Way ANOVA test. There was no significant difference in the transversal strength of the plate after being soaked for 31, 46, and 61 days in 4\%, 6\%,8\%, 10\%, and 12\% concentrations of the juice. This study showed that the soaking of acrylic resin plate for 31, 46, and 61 days in 4\%, 6\%, 8\%, 10\%, and 12\% concentrations of noni fruit juice does not decrease the transversal strength.
\end{abstract}

Key words: transversal strength, acrylic resin plate, noni fruit juice

Correspondence: Sri Redjeki Indiani, c/o: Departemen Material dan Kedokteran Gigi, Fakultas Kedokteran Gigi Universitas Airlangga. Jln. Mayjend. Prof. Dr. Moestopo 47, Surabaya 60132, Indonesia.

\section{INTRODUCTION}

Nowadays, acrylic resin is widely applied as a denture base. However, acrylic resin has disadvantages such as its liquid absorbing ability and micro porosity, allowing food debris to accumulate. Microorganisms can easily colonize and grow, especially microorganisms which can contribute to plaque formation. ${ }^{1}$ Saliva has not only the function of lubricating, but also protecting, oral tissue and as medium for microorganisms to survive and to develop. ${ }^{2}$ Saliva can form a pellicle on the surface of acrylic resin plate resulting in adhesion of microorganisms such as Candida albicans (C. albicans). ${ }^{3}$

Plaque accumulation in dentures is mostly found not only on the fitting surface location in the maxilla or mandible, but also on the polished side of the sublingual. ${ }^{4}$ There is significant correlation between bad denture hygiene and inflammation. ${ }^{5}$ An increase in the presence of Candida albicans is usually followed by increased toxin production which can penetrate into the mucous membranes and result in inflammation. Therefore, the acrylic resin based denture user should always pay particular attention to denture hygiene. In elderly patients with poor attention to oral hygiene, use of a mild antiseptic mouth rinse is recommended to reduce pathogenic microorganisms in the oral cavity such as Candida albicans, and to prevent denture stomatitis. Gargling is a mechanical activity and has an anti-microbial effect. ${ }^{6}$
Noni fruit (Morinda citrifolia Linn.) is a tropical plant used for thousands of years in the traditional treatment of various diseases. It contains saponin, flavonoid, atsiri oil, and alkaloids, which have been found to be anti bacterial and anti-fungal, ${ }^{7}$ and specifically effective against Escherichia coli, Stapilococcus aureus, and Pseudomonas aeroginosa. ${ }^{8}$

It is currently reported that noni fruit juice is used not only as a drink but also in gargling therapy. ${ }^{8,9}$ As a mouth rinse it should be used two or three times a day or whenever needed. ${ }^{9}$ This previous study reported that a growth of C. albicans colony did not occur when acrylic resin plate was immersed in over $12.5 \%$ noni fruit juice and incubated with $C$. albicans for twenty four hours in a solid media. ${ }^{10}$ This is the basis for establishing the concentration used in this study.

The chemical composition of noni fruit consists of flavonoid, which is a phenol substance, ${ }^{11}$ a substance known to degrade acrylic resin denture when in prolonged contact. ${ }^{12}$ Five percent phenol would weaken acrylic polymer bond and it would penetrate and soften the resin after 2 hours of immersion. The degradation of acrylic resin would decrease the mechanical character such as transverse strength. ${ }^{13}$ Transverse strength is the resistance of the denture strength to pressure and pulling force during normal functioning.

The duration of acrylic resin immersion in noni fruit juice is based on the assumption that the patient would 
gargle two to four times per day, with an ideal duration of denture use being approximately a 4-years period..$^{10,14}$ Therefore in this study the acrylic resin plate was immersed for 61 days.

The purpose of study were to examine the transversal strength of the acrylic resin plate after being immersed in noni fruit juice for some period of times and to determine the concentration of juice and duration of immersion which cause no effect on transversal strength of acrylic resin plate.

\section{MATERIALS AND METHODS}

Materials used in this study were hard gypsum (Moldano, Bayer), heat cured acrylic resin (QC, England), cold mould seal (Detrey, England), sandpaper no. 300 and 600 (Sail Brand, China), the juice of the noni fruit, and distilled water. The tools used were a metal master, model $65 \times 10 \times 2.5 \mathrm{~mm}$, a porcelain bowl, cuvet, press and curing unit, an autograph AG-10 TE (Shimadzu), and a light microscope.

Acrylic resin plate preparation: gypsum and water were mixed in a ratio of 100 gr of gypsum in $24 \mathrm{ml}$ of water (based on factory procedure). The mix was manually stirred for 12 seconds and then placed in a vacuum mixer for 30 seconds. The mix was placed into a cuvet, which was placed on the vibrator, and the gypsum paste was set for 60 minutes. The surface of gypsum was polished with vaseline, and the upper cuvet was filled with gypsum paste on the vibrator. After the gypsum was hardened, the cuvet was opened and the metal master model removed, cleaned in hot water. The next step was the application of an appropriate separating medium onto the walls of the mold cavity, allowing it to dry for 20 minutes (based on factory procedure).

Acrylic filling: the material of acrylic resin was mixed with the powder and the liquid based on factory procedure (11.5 mg powder and $5 \mathrm{cc}$ of liquid) and was placed into a porcelain bowl, then vibrated. After the paste reached the consistency of dough, it was placed into the mold, which was polished by separation material. The cuvet was closed and pressed by a hydraulic press. The cuvet was slowly opened and excess acrylic was cut. Then, the cuvet was closed and pressed again until the pressure reached $22 \mathrm{~kg} / \mathrm{cm}^{2}$. Next, the cuvet was moved to a clamp.

Curing process: the cuvet containing the acrylic was placed into the curing unit. The process was carried out at $100^{\circ} \mathrm{C}$ for 30 minutes (based on factory procedure). After the curing process was completed, the cuvet was cooled and then the specimen was removed from the cuvet. To smooth out the tested plate of acrylic resin it was held under running water and sanded using 300-600 sandpaper until the size reached $65 \times 10 \times 2.5 \mathrm{~mm}$. Finally, it was placed into a closed tube to avoid drying. The samples were classified into 6 groups, each group consisting of 16 samples.
The fruit of the noni tree (Morinda citrifolia Linn.), which can be found in the Sutorejo area of East Java, Indonesia should be ripe and stringent in odor, a transparent yellowish white in color, and with a soft, juicy texture, and with a diameter of not less than $7 \mathrm{~cm}$. It must be washed and the outer part peeled, the juice squeezed and classified into 5 groups consisting of concentrations of $4 \%, 6 \%, 8 \%$, $10 \%, 12 \%$ in amounts of $20 \mathrm{ml}$ each.

The acrylic resin plate was immersed in $50 \mathrm{ml}$ of noni fruit juice in a transparent bottle and loosely closed for 31,46 , and 61 days in every concentration group. Control groups were immersed in distilled water in the same duration. During the immersing process, the plate was positioned upright allowing the whole surface to be immersed. The immersion solution was changed everyday. After the immersion process was completed, the acrylic resin plate was washed in distilled water and dried. Finally, it was tested for transverse strength.

The test of transverse strength was done using an autograph AG-10 TE with a cross head speed of $1 / 10 \mathrm{~mm} /$ second. The distance between supports was $50 \mathrm{~mm} .^{15,16}$ The result was obtained using the equation:

$$
\mathrm{S}=\frac{3 \mathrm{IP}}{2 \mathrm{bd}^{2}} \mathrm{~kg} / \mathrm{cm}^{2}
$$

Note: $\mathrm{S}:$ Transversal strength $\left(\mathrm{kg} / \mathrm{cm}^{2}\right)$

1 : Length/distance supporting $(\mathrm{cm})$

$\mathrm{b}$ : Width of acrylic resin plate $(\mathrm{cm})$

$\mathrm{d}$ : Thickness of acrylic resin plate $(\mathrm{cm})$

P : Load $(\mathrm{kg})$

The data was analyzed using a One-Way ANOVA test with significance rate of $\alpha 0.05$.

\section{RESULT}

The mean and standard deviation of transversal strength of acrylic resin plate soaked in $4 \%, 6 \%, 8 \%, 10 \%$, and $12 \%$ concentrations of noni fruit juice and water for 31 and 46 and 61 days is shown in Table 1.

A Kolmogorof Smirnov test was carried out on the data to determine the normality of distribution. The result of every tested group showed $p>0.05$, therefore all the data had normal distribution. A Levene test was done to determine the data homogenity and the significant rate was 0.214 ( $p>0.05$ ) for the duration of immersion, meaning the data was homogenous. Therefore, a One-Way ANOVA test was done and showed $p>0.05(p=1.000)$ so a significant difference was not found in the transverse strength of acrylic resin plate after being submersed in noni fruit juice between the control group (distilled water) and 4\%, 6\%, 8\%, 10\%, $12 \%$ concentrations of juice. A concentration group of $p>0.05(p=0.965)$ was obtained from a One-Way ANOVA test on transverse strength due to the duration of soaking; 
Table 1. The mean and standard deviation of transversal strength of acrylic resin plate after to immersion in noni fruit juice and distilled water $\left(\mathrm{N} / \mathrm{m}^{2}\right)$

\begin{tabular}{cccc}
\hline \multirow{2}{*}{ Concentration } & 31 days of immersion & 46 days of immersion & 61 days of immersion \\
\cline { 2 - 4 } & $\overline{\mathrm{X}} \pm \mathrm{SD}$ & $\overline{\mathrm{X}} \pm \mathrm{SD}$ & $\overline{\mathrm{X}} \pm \mathrm{SD}$ \\
\hline Distilled water & $144.68 \pm 9.34$ & $144.50 \pm 9.61$ & $144.50 \pm 12.77$ \\
4\% juice & $143.78 \pm 8.57$ & $144.44 \pm 6.99$ & $144.73 \pm 7.78$ \\
6\% juice & $143.93 \pm 11.03$ & $144.56 \pm 9.91$ & $144.88 \pm 6.57$ \\
$8 \%$ juice & $144.38 \pm 10.54$ & $144.82 \pm 8.86$ & $144.11 \pm 8.22$ \\
$10 \%$ juice & $144.45 \pm 8.01$ & $144.03 \pm 9.36$ & $144.38 \pm 9.80$ \\
$12 \%$ juice & $144.16 \pm 7.41$ & $144.19 \pm 9.09$ & $144.73 \pm 8.04$ \\
\hline
\end{tabular}

no significant difference was found in transversal strength of acrylic resin plate immersed in the noni fruit juice for 31,46 , and 61 days.

Decrease of transversal strength of acrylic resin plate was not found after being immersed in noni fruit juice in $4 \%, 6 \%, 8 \%, 10 \%, 12 \%$ concentrations and distilled water or after being soaked for 31,46 , and 61 days. The result was supported by a topography test on the surface of acrylic resin plate using a light microscope with $500 \times$ magnification (Figure 1 and 2).

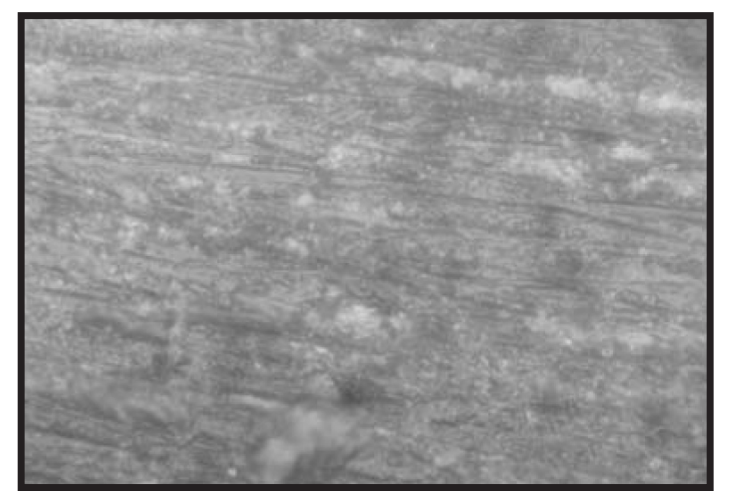

Figure 1. Topography on the surface of acrylic resin plate after immersion in distilled water for 61 days. Degradation was not seen on the surface of the acrylic resin plate (500× magnification).

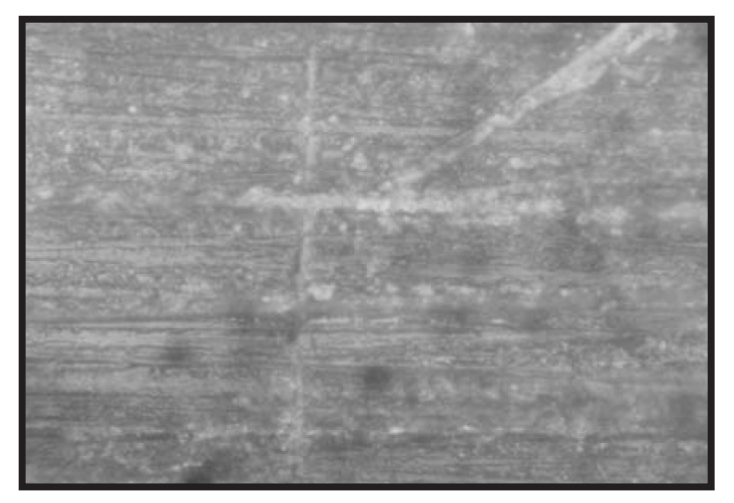

Figure 2. Topography on the surface of acrylic resin plate after being soaked in $12 \%$ concentration of noni fruit juice for 61 days, degradation was not seen on the surface of the acrylic resin plate $(500 \times$ magnification).

\section{DISCUSSION}

The previous study proved that no growth of C.albicans colony was present in noni fruit juice with a concentration above $12.5 \%$ when incubated with C.albicans for 24 hours. The mouth rinse is an oral antiseptic to prevent microorganism growth. ${ }^{17}$ In order not to irriate the mucous membranes, the concentration of mouth rinse should be lower than $12,5 \%$, classified into 5 groups according to the arithmetical progression of $4 \%, 6 \%, 8 \%, 10 \%, 12 \%$ with interval 2.

Based on ADA specification no. 12, that solubility of dental plastic in water is not higher than $0.04 \mathrm{mg} / \mathrm{cm}^{2}$, acrylic resin solubility in water $0,02 \mathrm{mg} / \mathrm{cm},{ }^{1}$ the immersion process of acrylic resin plate in water was used as a control group.

The immersion duration of acrylic resin in noni fruit juice is based on the assumption that a patient would gargle 2-4 times per day. It is estimated that each time gargling is done; noni fruit juice residue would be left in the oral cavity \pm 15 minutes, so in one day the acrylic resin would be immersed for 60 minutes. The life of a denture is ideally 4 years, ${ }^{14}$ which is equal to $(1 \times 365 \times 4)$ hour $=1460$ hours, an estimated 61 days. If the patient gargles three times per day, the soaking would be 46 days, and gargling twice per day the immersion would be 31 days if the control group were immersed in distilled water for the same duration.

The mean of transversal strength of acrylic resin plate soaked in noni fruit juice (Table 1) shows the immersion with higher concentration and longer duration will not decrease transverse strength. A One-Way ANOVA test, shows no significant difference in the transverse strength of the plate after being immersed in noni fruit juice in $4 \%, 6 \%$, $8 \%, 10 \%, 12 \%$ concentrations and also in distilled water for 31 days, 46 days and 61 days, showing that decrease in transversal strength does not occur. Acrylic resin is a long chain polymer of ester substance easily hydrolyzed and accelerated by acid and water. The acidity of the flavonoid content of noni fruit is not as strong as phenol. ${ }^{10}$ The data obtained from the photochemical laboratory of Airlangga University pharmacy shows that the total flavonoid content of dry noni fruit extract is $0.0863 \%$, for noni fruit juice is much lower when compared to dry noni fruit extract. Consequently, if it is exposed to acrylic resin 
plate in relatively long duration, the hydrolysis reaction of polymethil methacrylate does not occur, so polymer chain bonding is not disturbed. Therefore, degradation of acrylic resin does not occur and the transverse strength does not decrease due to the relatively good strength of acrylic resin against weak acid. ${ }^{1,19}$ The level of destruction due to acrylic immersion in disinfectant material depends on the immersion duration, the higher concentration of the disinfectant the worse the degradation will be. ${ }^{12}$

Transverse strength is one physical parameter to examine the dental base strength in tolerating force during mastication. The test shows the specimen strength to sustain high force and give deflection - the higher the fragility of material the lower the deflection and the risk of damaging the acrylic plate. ${ }^{13}$ The transverse strength of heat cured acrylic resin for dentures should be less than $50 \mathrm{~N} / \mathrm{mm}$. 2,18 The mean of transverse strength of acrylic resin plate immersed in distilled water for 61 days is $144.50 \mathrm{~N} / \mathrm{mm}$, ${ }^{2}$ and the mean of transverse strength of acrylic resin plate immersed in the highest concentration of $12 \%$ noni fruit juice for 61 days is $144,73 \mathrm{~N} / \mathrm{mm}^{2}$. The result is still above the standard which has been recommended. ${ }^{18}$ It can be seen with topographic imaging that the surface of acrylic resin using a light microscope with 500x magnification shows no degradation on the surface of the acrylic resin (Figures1 and 2).

The study shows that the immersion duration of acrylic resin plate for $31,46,61$ days in $4 \%, 6 \%, 8 \%, 10 \%$, $12 \%$ concentrations of noni fruit juice does not decrease the transversal strength. Further study is necessarily to determine the total flavonoid content in noni fruit juice.

\section{REFERENCES}

1. Craig RG, Peyton FA. Restorative dental material. $5^{\text {th }}$ ed. St Louis: The Mosby Co; 2002. p. 388-485.

2. Sumarijah S. Respon imun humoral terhadap streptococcus sanguis pada Recurrent Apthous Stomatitis (RAS). Dissertation. Surabaya: Pasca Sarjana Unair; 1985. p. 9-20.
3. Edgerton M, Levine M. Characterization of acquired denture pellicle from healthy and stomatitis patients. J Prosthet Dent 1992; 68:683-91.

4. Siong BK, Lim M. Denture plaque distribution and effectiveness of a perborate- containing denture cleanser. Quint Int 1996; 27:341-5.

5. Kulak Y, Arikan. An etiology of denture stomatitis. Journal of Marmara University Dental Faculty 1993; 4:307-14.

6. Sweet JB, Macynski AA. Effect of antimicrobial mouth rinse on incidence of localized alveolitis and infection following mandibular third molar oral surgery. Oral med Oral Phathol 1985; 59:24-6.

7. Syamsuhidayat SS, Hutapea JR. Inventarisasi tanaman obat Indonesia I. Jakarta: Balai Penerbitan dan QS Pengembangan Kesehatan; 1991. p. 390-1.

8. Goretti MW. Sehat dengan mengkudu. $2^{\text {th }}$ ed. Jakarta - Indonesia: MSF Group; 2000. p. 3-17.

9. Brown IN. 53 ways to use Noni fruit juice for your better health. A handbook of oral, topical and internal application and procedures. Utah: Pride Publishing; 1998. p. 177-82.

10. Indiani SR. Efek perasan buah mengkudu sebagai perendam resin akrilik terhadap keberadaan Candida albicans. Majalah Kedokteran Gigi (Dental Journal) 2003; Edisi Khusus Temu Ilmiah Nasional III: $13-6$.

11. Pramono S. Diktat kuliah tinjauan umum senyawa fenol nabati. Yogyakarta: Fakultas Pascasarjana, Universitas Gajah Mada; 1988. p. 34-9.

12. Shen C, Nikzad S, Javid. The effect of glutaraldehyde base disinfectants of denture base resins. J Prosthet Dent 1989; 61(5): 583-8.

13. Attin T, Vattaschiki M, Hellwig E. Properties of resin modified glass-ionomer restorative material and two polyacid modified resin composite material. Quint Int 1996; 27:203-9.

14. American Dental Association (ADA). Guide to dental material and devices. $7^{\text {th }}$ ed. Chicago. 1974. p. 70-106.

15. Robinson JG, Mc Cabe JF, Storer R. The whitening of acrylic resin dentures: The role of denture cleansers. J Br Dent 1985; 19:247-50.

16. Reitz PV, Sanders JL, Levin B. The curing of acrylic resins by microwave energy: Physical properties. Dent Res Quint Int 1985; 8:547-51.

17. Jawets E, Melnick JL, Adelberg EA. Mikrobiologi untuk profesi kesehatan (Review of Medical Microbiology) Tonang H, editor. Edisi 16. Jakarta: EGC; 1991. p. 382.

18. Asad T, Watkinson AC, Huggett NR. The effect disinfection procedures on flexural property of denture base acrylic resins. J Prosthet Dent 1992; 68:191-5.

19. Billmeyer FW. Textbook of polymer science. $3^{\text {rd }}$ ed. New York, Chichester Brisbane, Toronto, Singapore: A Wiley-Interscience Publication. John Wiley and Sons; 1984. p. 11-6. 409-11. 